\title{
Behçet's Disease: The Clinical and Demographic Characteristics of 406 Patients
}

\author{
Behçet Hastalığı: 406 Hastanın Klinik ve Demografik Özellikleri
}

Merih SOYLU, Hande TAYLAN ŞEKEROĞLU, Elif ERDEM, Nihal DEMİRCAN

Department of Ophthalmology, Medical Faculty of Çukurova University, Adana, Turkey

Objectives: In this study, we aim to describe and investigate the demographic and clinical features, prognostic factors, ocular, and systemic manifestations of the patients with Behçet's Disease.

Patients and methods: The study included 406 patients (306 males, 100 females; 36.1 years; range 12 to 76 years) who met the classification criteria of the International Study Group for Behçet's Disease. The clinical and demographic characteristics including age at onset, sex, type of ocular involvement, visual acuity, systemic manifestations, and initial signs, and treatment modalities were reviewed.

Results: The mean age at onset was $27.6 \pm 7.2$ years in male patients and $29.0 \pm 9.3$ years in females. There were no significant differences between both sex in terms of the frequency of ocular involvement $(68.9 \%$ in male, $65.0 \%$ in female, $p=0.163)$ and bilaterality of the ocular involvement $(56.2 \%$ in male and $53.0 \%$ in female, $p=0.67)$. The most common initial presenting manifestation of the disease was oral aphthous ulcer which was seen in $71.9 \%$ of the patients, followed by ocular involvement $(23.4 \%)$. The leading clinical features were oral aphthous ulcers (100\%), followed by genital ulcers $(82.8 \%)$ and ocular manifestations (80.3\%). HLA-B51 was positive in 170 of 372 patients (45.7\%). HLA-B51 positivity had no effect on the frequency and severity of the ocular inflammatory episodes. Of 306 males, $141(46.1 \%)$ and of 100 females $29(29.0 \%)$ had severe ocular episodes, while $34.6 \%(n=106)$ of males and $21 \%(n=21)$ of females had frequent ocular involvement. Males had more frequent $(p=0.03)$ and more serious $(p=0.015)$ ocular inflammatory episodes than females. Cyclosporine A was the most commonly preferred agent for patients with frequent episodes $(24.3 \% ; p=0.019)$.

Conclusion: Ocular involvement in Behçet's disease is significantly more frequent and severe in men. The main prognostic criteria affecting the visual acuity are the severity and frequency of ocular involvement.

Key words: Behçet disease; HLA-B51; inflammatory episodes; uveitis; visual prognosis.
Amaç: Bu çalışmada Behçet hastalığı olan kişilerde hastalığın demografik ve klinik özellikleri, prognostik faktörleri, oküler ve sistemik bulgularının tanımlanması ve araştırılması amaçlandı.

Hastalar ve yöntemler: Çalışmaya Uluslararası Behçet Hastalığı Çalışma Grubu'nun sınıflama kriterlerini karşılayan 406 hasta (306 erkek, 100 kadın; ort. yaş 36.1; dağılım 12-76) dahil edildi. Başlangıç yaşı, cinsiyet, oküler tutulum tipi, görme keskinliği, sistemik bulgular ve başlangıç bulguları dahil olmak üzere klinik ve demografik özellikler ve tedavi yöntemleri gözden geçirildi.

Bulgular: Ortalama başlangıç yaşı erkeklerde 27.6 \pm 7.2 yıl, kadınlarda ise $29.0 \pm 9.3$ yıl idi. Oküler tutulum sıklığı (erkeklerde \%68.9, kadınlarda \%65; $p=0.163$ ) ve her iki gözde tutulum sıklığı (erkeklerde \%56.2, kadınlarda \%53.0; $\mathrm{p}=0.67$ ) açısından, her iki cinsiyet arasında anlamlı fark yoktu. Hastalığın en sık görülen ilk başlangıç bulgusu \%71.9 ile oral aftöz ülser iken, bunu \%23.4 ile oküler tutulum izliyordu. Başlıca klinik bulgu oral aftöz ülser iken (\%100), bunu genital ülser (\%82.8) ve oküler tutulum (\%80.3) izliyordu. HLA-B51, 372 hastanın 170'inde pozitifti (\%45.7). HLA-B51 pozitifliğinin oküler inflamatuvar atakların sıklığı ve ciddiyeti üzerinde bir etkisi yoktu. Üç yüz altı erkeğin 141'inde (\%46.1) ve 100 kadının 29'unda (\%29.0) ağır oküler atak mevcut olup, erkeklerin \%34.6'sında $(n=106)$ ve kadınların $\% 21$ 'inde $(n=21)$ sık oküler tutulum izlendi. Erkeklerdeki ataklar, kadınlarınkine göre daha sık $(p=0.03)$ ve daha ağırdı $(p=0.015)$. Siklosporin $A$, sık atak geçirenlerde en sık tercih edilen ilaçtı (\%24.3; $p=0.019)$.

Sonuç: Behçet hastalığında oküler tutulum erkeklerde anlamlı olarak daha sık ve ağır seyreder. Görme keskinliğini etkileyen başlıca prognostik kriter, oküler tutulumun sıklığı ve şiddetidir.

Anahtar sözcükler: Behçet hastalığı; HLA-B51; inflamatuvar atak; üveit; görme prognozu.

Received: November 25, 2011 Accepted: March 12, 2012

Correspondence: Hande Taylan Şekeroğlu, M.D. Çukurova Üniversitesi Tıp Fakültesi Göz Hastalıkları Anabilim Dalı, 01330 Balcalı, Adana, Turkey.

Tel: +90 322 - 3383181 e-mail: h_taylan@yahoo.com 
Behçet's disease is a multisystemic disease with occlusive vasculitis of unidentified origin. Today the criteria used the most to diagnose Behçet's disease are the same ones which were determined by the International Study Group for Behçet's Disease in $1990 .^{[1]}$ Diagnosis is often difficult, especially during the early stages of the disease.

The major symptoms are oral aphthous ulcers, genital ulcerations, skin lesions, and ocular manifestations. Ocular involvement is frequent and is mainly seen as posterior or panuveitis.

There are various systemic manifestations of the disease including skeletal system involvement such as arthritis, sacroiliitis, and spondyloarthropathy along with gastrointestinal, neurological, and vascular involvement. Even rare manifestations such as pericarditis, myocardial infarctions, epididymitis, and glomerulonephritis are possible. Life expectancy is shorter in young males than in females because of the tendency to have a more severe course of the disease in males. ${ }^{[2]}$ There are many treatment options available including systemic steroids, immunosuppressives, immunomodulatory drugs, and biological agents such as tumor necrosis factor-alpha (TNF- $\alpha$ ) inhibitors and interferon-alpha (INF- $\alpha$ ).

In the present study, the aim was to describe and investigate the demographic and clinical features, prognostic factors, ocular and systemic manifestations, regional characteristics, and treatment options of patients with Behçet's disease living in the Çukurova region, which is located in the southern part of Turkey.

\section{PATIENTS AND METHODS}

Four hundred and six consecutive patients (306 males, 100 females; 36.1 years; range 12 to 76 years) were enrolled in the study, which was conducted with patients who met the classification criteria of the International Study Group for Behçet's Disease, who had been followed up primarily by the Çukurova University Ophthalmology Department Uvea-Behçet Service, or who had been referred by the Rheumatology Department between 1995 and 2010. Therefore, the presence of ocular involvement was not the only inclusion criteria. All patients who had been diagnosed with Behçet's disease and who had been examined by the ophthalmology department were included. Demographic data including age, age at onset, gender, ocular findings including laterality, and the presence and type of uveitis along with visual acuity, systemic manifestations, and treatment modalities was collected from the medical records of the patients. Changes in visual acuity were assessed as an increase, decrease, or no change during follow-up only for those for whom eyes were involved. A rise in visual acuity was defined as an increase of one or more lines from initial visual acuity while a decline in visual acuity was defined as a decrease of one or more lines from initial visual acuity using the Snellen chart.

The initial manifestation of the disease leading to the diagnosis, and the ocular and extraocular manifestations at certain points in time were recorded. An ocular inflammatory episode was defined as an acute intraocular inflammation observed by slit-lamp microscopy or funduscopy. Patients who had only iridocyclitis, either with or without hypopyon, were classified as having anterior uveitis. Patients who had vitritis with retinitis and/or vasculitis were classified as having posterior uveitis, and those who had anterior and posterior uveitis at the same time were classified as having panuveitis.

A severe ocular inflammatory episode was defined as an acute episode with vitritis, retinitis, and vasculitis. Frequent attacks were defined as having more than three attacks per year.

Approval was obtained from the institutional review board before collection of the medical records.

All data was assessed using the Statistical Package for the Social Sciences (SPSS) software package version 14.0 (SPSS Inc., Chicago, Illinois, USA). Descriptive statistics were used for determining the distribution of the age, age at onset, sex, extraocular clinical manifestations, initial manifestations, type of ocular involvement, and treatment modalities. A chi-square test and Fisher's exact test were used for the categorical variables. A $p$ value of less than 0.05 was considered significant.

\section{RESULTS}

The male/female ratio was 3.1/1. The mean age at onset of the disease was 27.6 \pm 7.2 (range 11-48) years for males and 29.0 \pm 9.3 (range 14-71) years for females $(\mathrm{p}=0.139)$. The mean follow-up time was $5.1 \pm 4$.6 years (range 1-15).

The most common extraocular clinical manifestation was oral ulcers (100\%). The distribution of the extraocular manifestations of the disease during follow-up in both sexes is demonstrated in Table 1.

The most frequent initial manifestation was oral aphthous ulcers (71.9\%) followed by ocular involvement (23.4\%) (Table 2). 
Table 1. Extraocular clinical manifestations in 406 patients with Behçet's disease during follow-up

\begin{tabular}{|c|c|c|c|c|c|c|c|}
\hline \multirow{3}{*}{ Type of manifestation } & \multicolumn{6}{|c|}{ Patients } & \multirow[b]{3}{*}{$p$} \\
\hline & \multicolumn{2}{|c|}{ Total $(n=406)$} & \multicolumn{2}{|c|}{ Male $(n=306)$} & \multicolumn{2}{|c|}{ Female $(n=100)$} & \\
\hline & $\mathrm{n}$ & $\%$ & $\mathrm{n}$ & $\%$ & $\mathrm{n}$ & $\%$ & \\
\hline Oral ulcers & 406 & 100.0 & 306 & 100.0 & 100 & 100.0 & - \\
\hline Genital ulcerations & 336 & 82.8 & 254 & 83.0 & 82 & 82.0 & 0.879 \\
\hline Skin lesions & 113 & 27.8 & 86 & 28.1 & 27 & 27.0 & 0.898 \\
\hline Trombophlebitis & 35 & 8.6 & 30 & 9.8 & 5 & 5.0 & 0.156 \\
\hline Neurological involvement & 22 & 5.4 & 20 & 6.5 & 2 & 2.0 & 0.124 \\
\hline
\end{tabular}

Table 2. Type of initial manifestation in the 406 patients with Behçet's disease

\begin{tabular}{|c|c|c|c|c|c|c|c|}
\hline \multirow{3}{*}{ Initial manifestation } & \multicolumn{6}{|c|}{ Patients } & \multirow[b]{3}{*}{$p$} \\
\hline & \multicolumn{2}{|c|}{ Total $(n=406)$} & \multicolumn{2}{|c|}{ Male $(n=306)$} & \multicolumn{2}{|c|}{ Female $(n=100)$} & \\
\hline & $\mathrm{n}$ & $\%$ & $\mathrm{n}$ & $\%$ & $\mathrm{n}$ & $\%$ & \\
\hline Oral ulcers & 292 & 71.9 & 217 & 70.9 & 75 & 75.0 & \\
\hline Ocular involvement & 95 & 23.4 & 73 & 23.9 & 22 & 22.0 & \\
\hline Genital ulcerations & 7 & 1.7 & 5 & 1.6 & 2 & 2.0 & \\
\hline Arthritis & 5 & 1.2 & 4 & 1.3 & 1 & 1.0 & 0.737 \\
\hline Skin lesions & 4 & 0.9 & 4 & 1.3 & 0 & 0 & \\
\hline Neurological symptoms & 1 & 0.2 & 1 & 0.3 & 0 & 0 & \\
\hline Trombophlebitis & 2 & 0.5 & 2 & 0.7 & 0 & 0 & \\
\hline
\end{tabular}

Ocular involvement was observed in $80.3 \%(n=326)$ of the patients, and it was bilateral in $56.2 \%(\mathrm{n}=172)$ of men, and 53.0\% ( $\mathrm{n}=53)$ of women $(\mathrm{p}=0.677)$. There was no statistically significant difference in ocular involvement, anterior segment involvement, presence of hypopyon, presence of vitritis, or optic nerve head involvement between males and females. However, vasculitis and retinitis were seen more frequently in men than in women $(\mathrm{p}=0.001$ and $\mathrm{p}=0.001$, respectively). The ocular findings and type of uveitis according to gender are shown in Table 3 and Table 4.

An assessment for human leukocyte antigen B51 (HLA-B51) positivity was performed in only 372 patients. Positive results were found in 170 of 372 patients (45.7\%), with $47.7 \%$ being males (134/281) and $39.6 \%$ being females (36/91). The frequency of HLAB51 positivity was similar for both sexes $(\mathrm{p}=0.189)$, and it had no effect on the severity and frequency of the inflammatory episodes ( $\mathrm{p}=0.06$ and $\mathrm{p}=0.412)$.

Severe ocular episodes occurred in 141 out of 306 males (46.1\%) and 39 out of 100 females. Twenty-nine (29.0\%) had severe ocular episodes, and 106 of the males (34.6\%) and 21 of the females (21\%) had frequent ocular involvement. The frequency and severity of ocular inflammatory episodes were significantly higher in men compared with women $(\mathrm{p}=0.03 ; \mathrm{p}=0.01$, respectively) (Table 5).

Table 3. Ocular findings observed during the follow-up of 406 patients with Behçet's disease and distribution of the findings between genders

\begin{tabular}{|c|c|c|c|c|c|c|c|}
\hline \multirow{3}{*}{ Clinical finding } & \multicolumn{6}{|c|}{ Involved eyes } & \multirow[b]{3}{*}{$p$} \\
\hline & \multicolumn{2}{|c|}{ Total $(n=406)$} & \multicolumn{2}{|c|}{ Male $(n=306)$} & \multicolumn{2}{|c|}{ Female $(n=100)$} & \\
\hline & $\mathrm{n}$ & $\%$ & $\mathrm{n}$ & $\%$ & $\mathrm{n}$ & $\%$ & \\
\hline Anterior uveitis* & 183 & 45.1 & 132 & 43.1 & 51 & 51.0 & 0.138 \\
\hline Hypopyon & 35 & 8.6 & 27 & 8.8 & 8 & 8.0 & 0.643 \\
\hline Vitritis & 164 & 40.4 & 126 & 41.2 & 38 & 38.0 & 0.275 \\
\hline Retinitis & 114 & 28.1 & 97 & 46.4 & 17 & 20.5 & 0.001 \\
\hline Vasculitis & 111 & 27.3 & 93 & 30.4 & 18 & 18.0 & 0.001 \\
\hline Papillitis & 83 & 20.4 & 68 & 22.2 & 15 & 15.0 & 0.07 \\
\hline
\end{tabular}




\begin{tabular}{|c|c|c|c|c|c|c|c|}
\hline \multirow[t]{2}{*}{ Type of uveitis } & \multicolumn{2}{|c|}{ Total $(n=406)$} & \multicolumn{2}{|c|}{ Male $(n=306)$} & \multicolumn{2}{|c|}{ Female $(n=100)$} & \multirow[b]{2}{*}{$p$} \\
\hline & $\mathrm{n}$ & $\%$ & $\mathrm{n}$ & $\%$ & $\mathrm{n}$ & $\%$ & \\
\hline Anterior uveitis ${ }^{*}$ & 40 & 9.9 & 26 & 8.5 & 14 & 14 & 0.12 \\
\hline Posterior uveitis & 231 & 56.9 & 181 & 59.2 & 50 & 50 & 0.13 \\
\hline Panuveitis & 140 & 34.5 & 103 & 34 & 37 & 37 & 0.55 \\
\hline
\end{tabular}

Systemic corticosteroids were mainly used during acute inflammatory episodes and were tapered during remission since systemic immunosupressives or immunomodulatory drugs were preferred for maintenance therapy. Cyclosporin A was found to be the most preferred agent for patients having more frequent ocular inflammatory episodes (24.3\%) $(\mathrm{p}=0.019)$.

The changes in visual acuity are described in Table 6. The number of male patients who had a decrease in visual acuity during follow-up was higher compared with the number of females; however, there was no statistical difference in visual acuity changes between genders.

The factors which could affect the final visual acuity were analyzed by using multivariate logistic regression analysis. The results showed that the most significant factors were the frequency $(p=0.006)$ and severity $(p=0.004)$ of the inflammatory episodes. The age at onset $(p=0.221)$, gender $(p=0.835)$, HLAB51 positivity $(\mathrm{p}=0.95)$, and presence of neurological involvement $(p=0.190)$ were found to have no statistically significant effect on the final vision according to the regression analysis.

\section{DISCUSSION}

Behçet's disease has well defined endemic preferences. Regional differences in clinical characteristics may exist between populations. The highest incidence is seen along the ancient Silk Road from the Mediterranean countries to the Middle East, particularly between $30^{\circ}$ and $45^{\circ}$ latitude north, and in Turkey. ${ }^{[3-5]}$ The prevalence of Behçet's disease is 8-37/10.000 in Turkey. ${ }^{[6]}$ Gül et al. ${ }^{[7]}$ calculated in their familial aggregation study a sibling recurrence risk ratio, defined as the ratio of the risk of being affected among the siblings of the patients or the risk of being affected in the general population, of between 11.4 and 52.5. This supports the fact that a deep genetic background for the disease is present. Our hospital is the tertiary referral center in southern Turkey. Many people with different genetic properties currently live in this area, and their medical records may help improve the understanding of the course of the disease in one of the endemic areas in Turkey.

\begin{tabular}{|c|c|c|c|c|c|}
\hline \multirow[t]{2}{*}{ Characteristics of episodes } & \multicolumn{2}{|c|}{ Male $(n=306)$} & \multicolumn{2}{|c|}{ Female $(n=100)$} & \multirow[b]{2}{*}{$p$} \\
\hline & $\mathrm{n}$ & $\%$ & $\mathrm{n}$ & $\%$ & \\
\hline \multicolumn{6}{|l|}{ Frequency } \\
\hline Rare & 200 & 65.4 & 79 & 79.0 & \multirow{2}{*}{0.03} \\
\hline Frequent & 106 & 34.6 & 21 & 21.0 & \\
\hline \multicolumn{6}{|l|}{ Severity } \\
\hline Mild & 165 & 54.0 & 71 & 71.0 & \multirow{2}{*}{0.01} \\
\hline Severe & 141 & 46.1 & 29 & 29.0 & \\
\hline
\end{tabular}

Table 6. Changes in visual acuity of the involved eyes during follow-up between genders

\begin{tabular}{|c|c|c|c|c|c|c|c|c|c|}
\hline \multirow{3}{*}{ Type of manifestation } & \multicolumn{6}{|c|}{ Visual acuity changes } & & & \multirow[b]{3}{*}{$p$} \\
\hline & \multicolumn{2}{|c|}{ Decrease } & \multicolumn{2}{|c|}{ Increase } & \multicolumn{2}{|c|}{ No change } & \multicolumn{2}{|c|}{ Total } & \\
\hline & $\mathrm{n}$ & $\%$ & $\mathrm{n}$ & $\%$ & $\mathrm{n}$ & $\%$ & $\mathrm{n}$ & $\%$ & \\
\hline Males & 46 & 21 & 39 & 17.8 & 134 & 61.2 & 219 & 71.6 & \multirow[b]{2}{*}{0.453} \\
\hline Females & 10 & 14.9 & 10 & 14.9 & 47 & 70.2 & 67 & 67.0 & \\
\hline
\end{tabular}


The male-to-female ratio calculated in the present study was higher than found in other large cohorts. ${ }^{[8,9]}$ This difference could be the result of the referral pattern of the neighboring regions. Patients with more severe and frequent episodes (mostly males) were referred more often, so our findings may represent the worst spectrum of the disease.

The frequency of extraocular manifestations was similar to that found in other literature. The most common presentation of the disease in our study was oral aphthous ulcerations, and this is in concordance with most other studies from Turkey, Europe, and the United States. However, it was higher than the rate of $39.7 \%$ found in Egypt. ${ }^{[10-14]}$ Tugal-Tutkun et al. ${ }^{[1]}$ showed in their large observational case series that the rate of genital ulcers was $59.8 \%$. This is lower than the rate found in our present study $(82.8 \%)$, which might reflect the heterogenity of the population living in the Çukurova region since this part of Turkey has distinct ethnic properties compared with other regions.

The disease was found to be strongly associated with the major histocompatibility complex antigen HLA-B51 in the literature, ${ }^{[5]}$ but whether HLA-B51 positivity is correlated with the prognosis of the disease is still a matter of discussion. ${ }^{[15,16]}$ In the present study, no significant association between HLA-B51 positivity and severity or frequency of the inflammatory episodes was demonstrated, which contrasts with our previous study. ${ }^{[17]}$ This could be the result of the higher number of patients who were tested for HLA-B51 in this study. Other genetic and/ or environmental factors seem to be more important than HLA-B51 when examining the severity and progression of Behçet's disease. ${ }^{[15]}$ The ocular involvement rate $(80.3 \%)$ was higher compared with earlier reports. ${ }^{[10,18]}$ Ocular manifestations as initial symptoms were reported in $10-20 \%$ of the patients. ${ }^{[19]}$ This rate was similar to the one found in this study (23.4\%). Our study population was composed of completely of patients with Behçet's disease who were admitted directly or referred to our clinic regardless of their ocular involvement status. This may explain the lower frequency of ocular manifestation as an initial presentation of the disease. The ocular disease most commonly associated with Behçet's is recurrent nongranulomatous uveitis with necrotizing obliterative vasculitis. This affects the anterior or posterior segment of the eye or both. Unilateral involvement presents usually with anterior uveitis, but bilateral panuveitis with a chronic relapsing course is seen in $75 \%$ of patients. Posterior involvement is more serious. ${ }^{[20]}$ The main finding of the anterior disease in the past was anterior uveitis with hypopyon, ${ }^{[21]}$ but this is very rare today due to early diagnosis and proper treatment. In the present study, the rate of hypopyon was $7.4 \%$ at initial presentation. The most common type of ocular involvement was posterior uveitis $(56.9 \%)$. This rate was higher than what was found in other literature. ${ }^{[11,22-24]}$ In our study, it was shown that women have a more favorable prognosis than men. This could be related to the higher frequency and preponderance of severe inflammation (retinitis and vasculitis) in men. Males had more frequent $(\mathrm{p}=0.03)$ and more serious $(\mathrm{p}=0.01)$ ocular involvement than females. Men had a significantly higher number of inflammatory episodes with vasculitis and/or retinitis. This is in concordance with the findings of the study by Tugal-Tutkun et al. ${ }^{[11]}$ which showed that the ocular attacks with hypopyon, vitritis, vasculitis, and papillitis were significantly more frequent in men in Turkey. We found that the most preferred systemic treatment was systemic corticosteroids alone or in combination with immunosuppressive or immunomodulatory drugs. Kump et al. ${ }^{[25]}$ demonstrated in their large series that systemic corticosteroid treatment was used in $96 \%$ of patients in the 1960 s and $84 \%$ in the 1990 s. The use of steroids, especially as monotherapy, fell significantly from 1960 to 2000 . This supports the fact that there is an inevitable predilection toward using corticosteroid sparing agents, especially azathioprine and cyclosporine $\mathrm{A}^{[1,25-27]}$ because of the various side effects associated with steroids. As a result, we can conclude that in Behçet's disease, the main prognostic factors affecting the visual acuity were severity and frequency of the inflammatory episodes.

The present study has several potential limitations that are common to most retrospective studies. There is the possibility of selection bias. It must be remembered that all patients with Behçet's disease were enrolled in the study whether an ocular manifestation was present or not. The population studied may not be homogeneous because it mainly consisted of patients who were referred from various clinics and because the Çukurova region is a heterogeneous community with large amounts of migration. This can result in immigration bias. There are many people living there from different ethnic groups who are members of socially, racially, and economically diverse populations.

The results of the study are comparable to those found in the previous literature and can not be generalized to 
apply to all patients with Behçet's disease. However, the results provide beneficial information that can be added to the literature concerning the regional characteristics of the disease in southern Turkey.

\section{Declaration of conflicting interests}

The authors declared no conflicts of interest with respect to the authorship and/or publication of this article.

\section{Funding}

The authors received no financial support for the research and/or authorship of this article.

\section{REFERENCES}

1. Criteria for diagnosis of Behçet's disease. International Study Group for Behçet's Disease. Lancet 1990;335:1078-80.

2. Deuter CM, Kötter I, Wallace GR, Murray PI, Stübiger N, Zierhut M. Behçet's disease: ocular effects and treatment. Prog Retin Eye Res 2008;27:111-36.

3. Verity DH, Marr JE, Ohno S, Wallace GR, Stanford MR. Behçet's disease, the Silk Road and HLA-B51: historical and geographical perspectives. Tissue Antigens 1999;54:213-20.

4. O'Duffy JD. Behçet's syndrome. N Engl J Med 1990;322:326-8.

5. Ohno S, Ohguchi M, Hirose S, Matsuda H, Wakisaka A, Aizawa M. Close association of HLA-Bw51 with Behçet's disease. Arch Ophthalmol 1982;100:1455-8.

6. Tüzün Y, Yurdakul S, Cem Mat M, Ozyazgan Y, Hamuryudan V, Tüzün B, et al. Epidemiology of Behçet's syndrome in Turkey. Int J Dermatol 1996;35:618-20.

7. Gül A, Inanç M, Ocal L, Aral O, Koniçe M. Familial aggregation of Behçet's disease in Turkey. Ann Rheum Dis 2000;59:622-5.

8. Tursen U, Gurler A, Boyvat A. Evaluation of clinical findings according to sex in 2313 Turkish patients with Behçet's disease. Int J Dermatol 2003;42:346-51.

9. Kaklamani VG, Vaiopoulos G, Kaklamanis PG. Behçet's Disease. Semin Arthritis Rheum 1998;27:197-217.

10. Kitaichi N, Miyazaki A, Iwata D, Ohno S, Stanford MR, Chams H. Ocular features of Behcet's disease: an international collaborative study. $\mathrm{Br} \mathrm{J}$ Ophthalmol 2007;91:1579-82.

11. Tugal-Tutkun I, Onal S, Altan-Yaycioglu R, Huseyin Altunbas H, Urgancioglu M. Uveitis in Behçet disease: an analysis of 880 patients. Am J Ophthalmol 2004;138:373-80.

12. Pipitone N, Boiardi L, Olivieri I, Cantini F, Salvi F, Malatesta R, et al. Clinical manifestations of Behçet's disease in 137 Italian patients: results of a multicenter study. Clin Exp Rheumatol 2004;22(6 Suppl 36):S46-51.

13. Calamia KT, Wilson FC, Icen M, Crowson CS, Gabriel SE, Kremers HM. Epidemiology and clinical characteristics of Behçet's disease in the US: a population-based study. Arthritis Rheum 2009;61:600-4.

14. El Menyawi MM, Raslan HM, Edrees A. Clinical features of Behcet's disease in Egypt. Rheumatol Int 2009;29:641-6.

15. Gül A, Uyar FA, Inanc M, Ocal L, Tugal-Tutkun I, Aral $\mathrm{O}$, et al. Lack of association of HLA-B ${ }^{\star} 51$ with a severe disease course in Behçet's disease. Rheumatology (Oxford) 2001;40:668-72.

16. Müftüoğlu AU, Yazici H, Yurdakul S, Pazarli H, Ozyazgan Y, Tüzün Y, et al. Behçet's disease: lack of correlation of clinical manifestations with HLA antigens. Tissue Antigens 1981;17:226-30.

17. Soylu M, Ersöz TR, Erken E. The association between HLA B5 and ocular involvement in Behçet's disease in southern Turkey. Acta Ophthalmol (Copenh) 1992;70:786-9.

18. Mendes D, Correia M, Barbedo M, Vaio T, Mota M, Gonçalves $\mathrm{O}$, et al. Behçet's disease-a contemporary review. J Autoimmun 2009;32:178-88.

19. Krause L, Köhler AK, Altenburg A, Papoutsis N, Zouboulis $\mathrm{CC}$, Pleyer U, et al. Ocular involvement in AdamantiadesBehçet's disease in Berlin, Germany. Graefes Arch Clin Exp Ophthalmol 2009;247:661-6.

20. Kural-Seyahi E, Fresko I, Seyahi N, Ozyazgan Y, Mat C, Hamuryudan V, et al. The long-term mortality and morbidity of Behçet syndrome: a 2-decade outcome survey of 387 patients followed at a dedicated center. Medicine (Baltimore) 2003;82:60-76.

21. Benezra D, Cohen E. Treatment and visual prognosis in Behçet's disease. Br J Ophthalmol 1986;70:589-92.

22. Ambresin A, Tran T, Spertini F, Herbort C. Behçet's disease in Western Switzerland: epidemiology and analysis of ocular involvement. Ocul Immunol Inflamm 2002;10:53-63.

23. Sakamoto M, Akazawa K, Nishioka Y, Sanui H, Inomata $\mathrm{H}$, Nose Y. Prognostic factors of vision in patients with Behçet disease. Ophthalmology 1995;102:317-21.

24. Ozdal PC, Ortaç S, Taşkintuna I, Firat E. Posterior segment involvement in ocular Behçet's disease. Eur J Ophthalmol 2002;12:424-31.

25. Kump LI, Moeller KL, Reed GF, Kurup SK, Nussenblatt RB, Levy-Clarke GA. Behçet's disease: comparing 3 decades of treatment response at the National Eye Institute. Can J Ophthalmol 2008;43:468-72.

26. Ozdal PC, Ortaç S, Taskintuna I, Firat E. Long-term therapy with low dose cyclosporin A in ocular Behçet's disease. Doc Ophthalmol 2002;105:301-12.

27. Yazici H, Pazarli H, Barnes CG, Tüzün Y, Ozyazgan Y, Silman A, et al. A controlled trial of azathioprine in Behçet's syndrome. N Engl J Med 1990;322:281-5. 